Jurnal Keperawatan Silampari

Volume 2, Nomor 2, Juni 2019

e-ISSN: 2581-1975

p-ISSN: 2597-7482

DOI: https://doi.org/10.31539/jks.v2i2.535

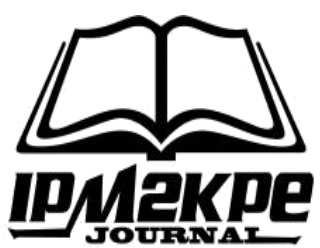

\title{
EFFEKTIVITAS METODE EDUKASI BRAINSTRORMING UNTUK MENINGKATKAN PEMAHAMAN KASUS DI LAHAN PRAKTIK PADA MAHASISWA PROFESI NERS
}

\author{
NH. Noeraini ${ }^{1}$, Yeni Eliyanti ${ }^{2}$, Dita Amita $^{3}$ \\ Program Studi Kesehatan Masyarakat, STIKES Bhakti Husada Bengkulu ${ }^{1}$ \\ Program Studi Keperawatan, STIKES Bhakti Husada Bengkulu ${ }^{2,3}$ \\ hjnh.mur@gmail.com ${ }^{1}$
}

\begin{abstract}
ABSTRAK
Penelitian ini bertujuan untuk mengetahui efektifitas pembelajaran metode brainstorming terhadap kemampuan pemahaman kasus di lahan praktik. Rancangan penelitian yang digunakan adalah nonequivalent control group design yang terdiri dari kelompok eksperimen yaitu dengan perlakuan metode brainstorming dan kelompok kontrol dengan metode konvensional, kemudian semua kelompok dinilai tingkat pemahaman kasus pada saat pre dan post eksperimen. Hasil Penelitian ini, pada kelompok intervensi terlihat lebih bermakna dengan nilai $\mathrm{p}$ value 0,000 dibanding dengan kelompok kontrol. Simpulan, edukasi brainstorming lebih efektif untuk diterapkan untuk meningkatkan pemahaman kasus pada mahasiswa profesi Ners di lahan praktik.
\end{abstract}

Kata Kunci: Brainstorming, Edukasi, Pemahaman

\begin{abstract}
This study aims to determine the effectiveness of learning brainstorming methods on the ability to understand cases in the practice area. The research design used was nonequivalent control group design consisting of experimental groups, namely the treatment of brainstorming methods and the control group with conventional methods, then all groups assessed the level of understanding of the case at the time of pre and post experiment. The results of this study, the intervention group was seen to be more meaningful with a $p$ value of 0,000 compared to the control group. Conclusion, brainstorming education is more effective to be applied to improve the understanding of cases in Nurse profession students in the practice field.
\end{abstract}

Keywords: Brainstorming, Education, Understanding 


\section{PENDAHULUAN}

Praktek profesi ners merupakan serangkaian pendidikan formal yang harus ditempuh para perawat yang terdiri atas sembilan stase, yang terdiri atas keperawatan medikal bedah, keperawatan gawat darurat, keperawatan anak, keperawatan maternitas, keperawatan komunitas dan keluarga, keperawatan management, keperawatan jiwa dan gerontik. Dalam pelaksanaan proses praktek profesi mahasiswa dinilai secara individual maupun kelompok. Penilaian kelompok terdiri atas diskusi kelompok, presentasi jurnal kegiatan kelompok dimasyarakat, sedangkan penilaian individual terdiri atas penilaian pre-post conference, penilaian kinerja klinik, penilaian ujian akhir dan penilaian presentasi kasus individu. Dalam pelaksanaan praktik klinik, mahasiswa diberikan edukasi untuk melakukan asuhan keperawatan pada pasien yang dirawat disetiap stase yang mereka jalani. Edukasi dengan strategi melakukan asuhan keperawatan kepada pasien tidak hanya memberikan edukasi pada mahasiswa bagaimana mengatasi masalah pasien tapi juga memberikan edukasi pada mahasiswa untuk melakukan komunikasi therapeutik, pengkajian dan komunikasi. Pemahaman dan penguasaan mahasiswa terhadap kondisi pasien sangat menentukan kualitas asuhan keperawatan yang akan diberikan perawat terhadap pasien (Yonny, 2011).

Gambaran diatas merupakan hal nyata bahwa pentingnya pemahaman mahasiswa terhadap kasus dalam lahan praktek. Melalui kasus mahasiswa belajar memahami konsep penyakit, mempelajari bagaimana cara mengkaji pasien terhadap penyakit, dan belajar untuk menerapkan asuhan keperawatan yang tepat terhadap pasien. Mengingat perannya yang sangat penting, maka upaya untuk meningkatkan pemahaman kasus harus dilakukan dengan berbagai usaha. Rendahnya pencapaian pemahaman dan kebutuhan suatu usaha untuk mningkatkannya dinyatakan Karim (2011) bahwa berbagai usaha untuk menggapai pemahaman banyak dilakukan, namun pemahaman terhadap suatu pembelajaran tidaklah mudah. Hal ini dapat terjadi metode edukasi dalam proses pembelajaran baik di lahan praktek maupun diruang kelas masih bersifat ceramah, tanya jawab dan terkadang diikuti dengan kritikan-kritikan baik dari pembimbing maupun dari mahasiswa lainnya serta bersifat sangat serius. Kondisikondisi tersebut merupakanhambatan dalam proses pembelajaran yang mengakibatkan tidak maksimalnya pemahaman terhadap konten pembelajaran.

Menurut Bastable (2006) edukasi merupakan standar praktik keperawatan professional, dalam usaha edukasi harus menyertakan nilai psikososial, spiritual dan budaya yang dimiliki serta keinginan berparisipasi aktif. Pelaksanaan edukasi dapat dilakukan dengan berbagai metode diantaranya ceramah, diskusi, peragaan, metode cetakan/ leaflet, alat bantu audiovisual (AVA), role play, permainan, komputer, contoh kasus dan latihan-latihan afektif serta metode brainstorming (Notoatmodjo, 2007). Brainstorming merupakan metode edukasi yang dimodifikasi dari metode diskusi kelompok. Prinsipnya sama dengan metode diskusi kelompok. Bedanya pada permulaan, pemimpin kelompok memancing dengan satu masalah kemudian setiap peserta memberikan jawaban dan jawaban tersebut ditampung dan didiskusikan.Dalam penelitian Zhao (2010) dijelaskan bahwa brainstorming merupakan metode pemecahan masalah, metode ini telah diterapkan pada dunia pendidikan, ilmu teknik dan keperawatan (Bolin, Neuman, 2006 dalam Fang, 2013).

Menurut Balackova (2004) bahwa metode brainstorming memungkinkan peserta menjadi lebih produktif dan membuat suasana belajar menyenangkan. Produktivitas melalui pengembangan masalah-masalah yang dipecahkan atau memungkinkan peserta memahami materi dan selanjutnya ditunjukkan dengan hasil belajar yang lebih baik. 
Metode brainstorming diharapkan mampu menciptakan suasana pembelajaran menjadi lebih menyenangkan, sehingga mampu meningkatkan pemahaman tentang kasus pasien dilahan praktek yang hasil akhirnya diharapkan mahasiswa dapat memberikan asuhan keperawatan yang optimal pada pasien. Kajian ini menunjukkan bahwa edukasi yang diberikan oleh pendidik menjadi sangat penting bagi mahasiswa untuk memahami kasus dan melaksanakan asuhan keperawatan. Penggunaan metode edukasi brainstorming diharapkan meningkatkan pemahaman dan motivasi mahasiswa yang menghasilkan peningkatan pemahaman, perubahan perilaku belajar secara berkelanjutan.

Beberapa penelitian terkait edukasi terhadap peningkatan kemampuan dan nilai mahasiswa dalam belajar dilahan praktek banyak dilakukan dengan menggunakan metode diskusi, role play, contoh kasus, sedangkan menggunakan metode brainstorming masih terbatas, padahal strategi edukasi mempunyai peran penting dalam usaha meningkatkan pemahaman kasus dan perilaku mahasiswa untuk melakukan asuhan keperawatan pada pasien.

Hasil observasi dan wawancara di rumah sakit RSUD Dr. M. Yunus Bengkulu, diketahui bahwa proses pembelajaran kasus dilahan praktek dilakukan dengan metode diskusi dengan strategi mahasiswa mempresentasikan kasus diikuti oleh sesi tanya jawab, saran, kritik oleh pendidik terhadap mahasiswa, dalam proses tersebut terlihat peserta yang menguasai kasus dan memiliki kepercayaan diri tinggi yang akan terlihat aktif sedangkan siswa lain lebih banyak terlihat pasif, suasana diskusi juga terlihat sangat formal sehingga mahasiswa merasa cemas ketika mereka tidak mengusai kasus. Kondisi tersebut terjadi karena kurangnya penguasaan kasus, metode edukasi yang belum menyentuh mahasiswa dari segala aspek serta kurang bervariasinya metode edukasi terhadap mahasiswa. Berdasarkan uraian diatas, menjadi suatu alasan yang penting untuk dilakukan penelitian lebih lanjut terkait efektifitas metode edukasi brainstorming untuk meningkatkan pemahaman kasus dilahan praktek pada mahasiswa profesi ners di rumah sakit.

\section{METODE PENELITIAN Desain Penelitian}

Penelitian ini merupakan penelitian kuantitatif, dengan desain quasi-experimental yang bertujuan untuk mengungkapkan hubungan sebab akibat dengan cara melibatkan kelompok control disamping kelompok eksperimental, kemudian pada kedua kelompok tidak menggunakan teknik acak. Rancangan penelitian yang digunakan adalah nonequivalent control group design yang terdiri dari kelompok eksperimen yaitu denganperlakuan metode brain storming dan kelompok kontrol dengan metode konvensional, kemudian semua kelompok dinilai tingkat pemahaman kasus pada saat pre dan post eksperimen.

\section{Participant}

Populasi pada penelitian ini adalah mahasiswa profesi ners. Responden yang diikutkan dalam penelitian ini adalah responden yang memiliki kriteria sedang aktif dalam kegiatan ners, responden mampu diajak kerjasama dengan baik, melakukan intervensi saat bersama peneliti dan responden kooperatif serta bisa mengikuti instruksi. Penentuan besar sampel penelitian dalam penelitian ini menggunakan teknik total sampling yaitu seluruh populasi dijadikan sebagai sampel penelitian. Jumlah sampel yaitu 30 orang. 15 orang akan diberikan perlakuan brainstorming dan 15 orang lainnya akan diberikan perlakuan konvensional. 


\section{Proses Penelitian}

Penelitian ini dilakukan pada mahasiswa profesi ners sebanyak 30 orang. 15 orang akan diberikan perlakuan brainstorming dan 15 orang lainnya akan diberikan perlakuan konvensional. Dengan menggunakan kuesioner penelitian yang sudah dibuat peneliti dengan jumlah item pertanyaan kuesioner sebanyak 8 pertanyaan yang mana kuesioner tersebut sudah dilakukan uji validitas dan realibilitas.

\section{Statistik Analisis}

Analisis data ini diolah dengan menggunakan aplikasi SPSS. Deskriptif statistik dilakukan untuk menganalisa karakteritik mahasiswa Profesi Ners meliputi jenis kelamin, usia, status di Rumah Sakit serta perubahan pemahaman kasus sebelum dan sesudah intervensi.Menganalisa perbedaan pemahaman kasus pada kelompok intervensi dan kelompok kontrol sebelum dan sesudah diberikan intervensi pada kelompok intervensi dengan menggunakan uji dependent t-test (Paired sample t-test) dan perbedaan pemahaman kasus antara kelompok intervensi dengan kelompok kontrol setelah kelompok intervensi mendapat perlakuan menggunakan uji independent t-test.

\section{HASIL PENELITIAN Karakteristik Responden}

Tabel. 1

Distribusi Responden Menurut Jenis Kelamin dan Status responden

\begin{tabular}{|c|c|c|c|c|c|c|}
\hline \multirow[t]{3}{*}{ Jenis Kelamin } & \multicolumn{4}{|c|}{ Kelompok } & \multirow[t]{3}{*}{ Jumlah } & \multirow[t]{3}{*}{ Presentase } \\
\hline & \multicolumn{2}{|c|}{ Eksperimen } & \multicolumn{2}{|c|}{ Kontrol } & & \\
\hline & Jumlah & Presentase & Jumlah & Presentase & & \\
\hline \multicolumn{7}{|l|}{ Jenis Kelamin } \\
\hline Laki-Laki & 7 & 46.7 & 6 & 40.0 & 13 & 43.3 \\
\hline Perempuan & 8 & 53.3 & 9 & 60.0 & 17 & 56.7 \\
\hline Non Pegawai Tetap & 9 & 60.0 & 7 & 46.7 & 16 & 53.3 \\
\hline Pegawai Tetap & 6 & 40.0 & 8 & 53.3 & 14 & 46.7 \\
\hline Total & 15 & 100.0 & 15 & 100.0 & 30 & 100.0 \\
\hline
\end{tabular}

Berdasarkan tabel distribusi responden menurut jenis kelamin tersebut, jumlah responden yang berjenis kelamin laki-laki pada kelompok eksperimen lebih sedikit daripada kelompok kontrol, yaitu sebesar 7 (46,7\%), sedangkan pada kelompok kontrol sebanyak $6(40,0 \%)$ responden berjenis kelamin laki-laki. Sebaliknya, jumlah responden yang berjenis kelamin perempuan, lebih banyak ditemui pada kelompok kontrol, yaitu 9 $(60,0 \%)$ responden, sedangkan pada kelompok eksperimen, jumlah responden yang berjenis kelamin perempuan adalah sebanyak 8 (53,3\%). Secara keseluruhan, responden yang berjenis kelamin laki-laki pada kelompok eksperimen dan kontrol adalah sebanyak $13(43,3 \%)$ responden, sedangkan responden yang berjenis kelamin perempuan pada kelompok eksperimen dan kontrol adalah sebanyak 17 (56,7\%) responden.

Berdasarkan tabel distribusi responden menurut status di RS tersebut, jumlah responden yang non pegawai tetap pada kelompok eksperimen lebih banyak daripada kelompok kontrol, yaitu sebesar 9 (60,0\%), sedangkan pada kelompok kontrol sebanyak $7(46,7 \%)$ responden non pegawai tetap. Sebaliknya, jumlah responden yang pegawai tetap, lebih banyak ditemui pada kelompok kontrol, yaitu $8(53,3 \%)$ responden, 
sedangkan pada kelompok eksperimen, jumlah responden yang pegawai tetap adalah sebanyak $6(40,0 \%)$. Secara keseluruhan, responden yang non pegawai tetap pada kelompok eksperimen dan kontrol adalah sebanyak 16 (53,3\%) responden, sedangkan responden yang pegawai tetap pada kelompok eksperimen dan kontrol adalah sebanyak $14(46,7 \%)$ responden.

Tabel. 2

Karakteristik Responden Berdasarkan Usia

\begin{tabular}{cccccccc}
\hline \multirow{2}{*}{ Usia (Tahun) } & \multicolumn{9}{c}{ Kelompok } & Jumlah & Presentase \\
\cline { 3 - 6 } & & \multicolumn{2}{c}{ Eksperimen } & \multicolumn{2}{c}{ Kontrol } & & \\
& & Jumlah & Presentase & Jumlah & Presentase & & \\
\hline $22-30$ & 13 & 86.7 & 8 & 53.3 & 21 & 70.0 \\
$31-45$ & & 2 & 13.3 & 7 & 46.7 & 9 & 30.0 \\
& & 15 & 100.0 & 15 & 100.0 & 30 & 100.0 \\
\hline
\end{tabular}

Berdasarkan tabel distribusi responden menurut umur tersebut, diketahui bahwa pada kelompok eksperimen terdapat $13(86,7 \%)$ responden yang berumur 22-30 tahun, dan $2(13,3 \%)$ responden yang berumur 31-45 tahun. Distribusi responden menurut umur pada kelompok kontrol pun dapat diketahui, yaitu sebanyak $8(53,3 \%)$ responden berumur 22-30 tahun, dan 7 (46,7\%) responden yang berumur 31-45 tahun.

Tabel. 3

Rata-Rata Skor Pemahaman Mahasiswa terhadap Kasus Dilahan Praktek Sebelum dan Sesudah Perlakuan Kelompok Intervensi dan Kelompok Kontrol

\begin{tabular}{|c|c|c|c|c|c|c|}
\hline Variabel & Waktu & Kelompok & Mean & Median & SD & $\begin{array}{l}\text { Min-Mak } \\
(95 \% \mathrm{CI})\end{array}$ \\
\hline \multirow[t]{2}{*}{$\begin{array}{l}\text { Pemahaman } \\
\text { kasus }\end{array}$} & Pre test & Kontrol & 5,20 & 5,00 & 0,86 & $\begin{array}{c}4-6 \\
(4,72-5,68)\end{array}$ \\
\hline & & Intervensi & 7,13 & 8,00 & 3,66 & $\begin{array}{c}0-11 \\
(5,11-9,16\end{array}$ \\
\hline \multirow[t]{2}{*}{$\begin{array}{l}\text { Pemahaman } \\
\text { kasus }\end{array}$} & Post test & Kontrol & 6,60 & 7,00 & 1,64 & $\begin{array}{c}4-9 \\
(5,69-7,51)\end{array}$ \\
\hline & & Intervensi & 10,60 & 11,00 & 1,72 & $\begin{array}{c}7-13 \\
(9,65-11,55)\end{array}$ \\
\hline
\end{tabular}

Dari tabel diatas diketahui bahwa rata-rata pemahaman kasus sebelum perlakuan pada kelompok kontrol adalah 5,20 (SD =0,86). Dari hasil estimasi interval dapat disimpulkan bahwa 95\% diyakini rata-rata nilai pemahaman kasus kelompok control antara 4,72 - 5,68. Sedangkan pada kelompok intervensi rata-rata pemahaman kasus sebelum perlakuan pada kelompok intervensi adalah 7,13 (3,66). Dari hasil Dari hasil estimasi interval dapat disimpulkan bahwa $95 \%$ diyakini rata-rata nilai pemahaman kasus kelompok intervensi antara 5,11 - 9,16.

Rata-rata pemahaman kasus setelah perlakuan pada kelompok kontrol adalah 6,60 $(\mathrm{SD}=1,64)$. Dari hasil estimasi interval dapat disimpulkan bahwa $95 \%$ diyakini ratarata nilai pemahaman kasus kelompok kontrol antara 5,69 - 7,51. Sedangkan pada kelompok intervensi rata-rata pemahaman kasus setelah perlakuan pada kelompok intervensi adalah 10,60 (1,72). Dari hasil Dari hasil estimasi interval dapat disimpulkan 
bahwa 95\% diyakini rata-rata nilai pemahaman kasus kelompok intervensi antara 9,65 11,55 .

Tabel. 5

Hasil Analisis Perbedaan Pemahaman Kasus Mahasiswa Profesi Ners di Lahan Praktek pada Kelompok Intervensi dan Kelompok Kontrol

\begin{tabular}{clccccc}
\hline Variabel & Kelompok & Mean & SD & SE & P Value & N \\
\hline Pemahaman kasus & Kontrol & 6,60 & 0,862 & 0,400 & 0,004 & 15 \\
& Intervensi & 10,60 & 1,724 & 0,768 & 0,000 & 15 \\
\hline
\end{tabular}

Selisih rata-rata pemahaman kasus setelah dilakukan edukasi brainstorming pada kelompok kontrol adalah 6,60 $(\mathrm{SD}=0,862)$ dan kelompok intervensi 10,60 $(\mathrm{SD}=$ 1,724). Rata-rata pemahaman kasus kelompok intervensi lebih tinggi dari kelompok kontrol. Hasil uji statistic didapatkan p value 0,004 yaitu terdapat perbedaan bermakna secara statistik pada pemahaman kasus setelah dilakukan edukasi konvensional (kontrol), sedangkan p value 0,000 pada perlakukan edukasi brainstorming (intervensi) disimpulkan bahwa terdapat perbedaan bermakna secara statistik.

Dilihat dari hasil antara kelompok kontrol dengan kelompok intervensi bahwa terdapat perbedaan bermakna antara perlakuan yang diberikan. Kelompok intervensi terlihat lebih bermakna dengan $\mathrm{p}$ value 0,000 dibanding dengan kelompok kontrol. Hal ini membuktikan bahwa edukasi brainstorming lebih efektif untuk diterapkan untuk meningkatkan pemahaman kasus pada mahasiswa profesi ners di lahan praktik.

\section{PEMBAHASAN}

Notoatmodjo (2007) pendidikan kesehatan adalah rangkaian pembelajaran yang dilaksanakan secara terencana, didasarkan pada teori-teori yang logis dan membekali individu, kelompok dan masyarakat untuk mempengaruhi orang lain, mendapatkan informasi dan keterampilan guna membuat keputusan kesehatan yang bermutu dalam rangka meningkatkan taraf hidup sehat dan kesejahteraan masyarakat. Pendidikan kesehatan dalam penelitian ini merupakan pemberian pengetahuan dan pengalaman tentang kasus yang dijumpai oleh mahasiswa dilahan praktek meliputi konsep teoritis, integrasi ilmu dasar dalam kasus serta asuhan keperawatan.

Edukasi pada mahasiswa ners dilahan praktek merupakan suatu peran pendidikan keperawatan yang penting. Kebutuhan akan peningkatan pengetahuan siswa, serta kompetensi mahasiswa meningkatkan kebutuhan untuk memberikan informasi yang tepat serta dengan cara melakukan metode yang tepat serta menarik bagi mahasiswa. Dalam hal ini pendidik harus terus mencari cara untuk meningkatkan metode edukasi yang terbaik, agar peserta mendapatkan informasi secara komperhensif. Salah satu bentuk edukasi yang dapat dilakukan adalah dengan menggunakan edukasi brainstorming. Dalam hal ini edukasi brainstorming yang dilakukan menyangkut tentang konsep dasar penyakit, kondisi pasien (dalam bentuk kasus) dilahan praktek. Program edukasi brainstorming yang akan dilakukan membahas kasus dan teori meliputi pemahaman konsep penyakit, gambaran kasus, integritas konsep dengan kasus (Balakcova, 2004).

Edukasi yang perlu untuk dilakukan pada mahasiswa profesi ners agar dapat memahami kasus pasien, yaitu dengan menerapkan edukasi brainstorming. Keunggulan metode brainstorming adalah mahasiswa dapat aktif berpikir untuk menyatakan pendapat, dapatmelatih pasie berpikir cepat dan tersusun logis, kemudian merangsang 
pasien untuk selalu siap berpendapat yang sesuai masalah yang diberikan oleh penyaji, meningkatkan partisispasi klien dalam menerima pelajaran, suasana yang tercipta demokrasi dan disiplin dapat ditumbuhkan (Nuraisiyyah, 2008).

Brainstorming adalah suatu teknik atau cara mengajar yang dilaksanakan oleh guru di dalam kelas, dengan cara melontarkan suatu masalah ke kelas oleh guru, kemudian peserta didik menjawab atau menyatakan pendapat, atau komentar sehingga mungkin masalah tersebut berkembang menjadi masalah baru, atau dapat diartikan pula sebagai satu cara untuk mendapatkan ide dari sekelompok manusia dalam waktu singkat (Roestiyah, 2008).

Metode ini dikembangkan oleh seorang eksekutif periklanan Alex F. Osborn, ia mulai mengembangkan metode untuk memecahkan masalah secara kreatif pada tahun 1939. Dia frustrasi oleh ketidakmampuan karyawan untuk mengembangkan ide-ide kreatif individual untuk kampanye iklan. Sebagai tanggapan, ia mulai mengadakan suatu kelompok diskusi dan menemukan peningkatan yang signifikan dalam kualitas dan kuantitas ide yang dihasilkan oleh karyawan. Dan dalam perkembangannya kini, metode brainstorming juga diterapkan dalam proses belajar mengajar di berbagai lembaga pendidikan (Kimberly, 2013).

Metode brainstorming adalah teknik mengajar yang dilaksanakan dengan cara melontarkan suatu masalah ke mahasiswa profesi, kemudian mahasiswa menjawab, menyatakan pendapat, atau memberi komentar sehingga memungkinkan masalah tersebut berkembang menjadi masalah baru. Tujuan pembelajaran metode brainstorming mengacu pada penggalian ide berdasarkan kreativitas berfikir mahasiswa. Mahasiswa bebas menyampaikan pendapat tanpa rasa takut terhadap kritik dan penilaian sebab selama tahap pengumpulan ide semua gagasan akan ditampung tanpa terkecuali. Perbedaannya dengan metode konvensional, jika dalam diskusi gagasan dari seseorang ditanggapi (didukung, dilengkapi, dikurangi, atau tidak disepakati) oleh peserta lain, maka pada penggunaan metode brainstorming (curah pendapat) gagasan yang dikemukakan tidak untuk ditanggapi oleh peserta lain (Balakcova, 2004).

Dalam brainstorming klien diperbolehkan mengemukakan gagasan apa saja yang muncul dari pikiran masing-masing, tidak dibenarkan adanya kritik, karena adanya kritik dapat merintangi gagasan yang akan keluar. Dengan evaluasi dapat disimpulkan suatu jawaban dari berbagai pendapat yang diperoleh. Salah satu kelemahan metode brainstorming adalah guru kurang memberi waktu cukup untuk berpikir dengan baik. Brainstorming merupakan salah satu teknik untuk merangsang munculnya pemikiranpemikiran kreatif terutama dalam usaha pemecahan masalah. Rangsangan yang diberikan dapat berupa pertanyaan untuk tugas pemecahan masalah atau tugas melakukan kegiatan Roestiyah (1998) dalam Nuraisiyyah (2008).

Suprijanto (2009) brainstorming adalah salah satu bentuk berpikir kreatif sehingga pertimbangan memberikan jalan untuk berinisiatif kreatif. Peserta didorong untuk mencurahkan semua ide yang timbul dari pikirannya dalam jangka waktu tertentu berkenaan dengan beberapa masalah, dan tidak diminta untuk menilainya selama curah pendapat berlangsung. Penilaian akan dilakukan pada periode berikutnya dimana semua ide dipilih, dievaluasi dan mungkin diterapkan".

Seperti yang telah diketahui bahwa metode brainstorming adalah suatu teknik mengajar dengan melontarkan suatu masalah ke dalam kelas, kemudian peserta didik diminta menjawab, menyatakan pendapat atau berkomentar tentang masalah tersebut. Konstruktivisme sendiri merupakan suatu landasan berfikir yang menyatakan bahwa 
pengetahuan itu dibangun atau dikonstruksikan oleh manusia (pemikiran) sendiri, manusia mengkonstruksikan pengetahuannya berdasarkan fakta yang telah dialaminya atau pengalaman langsung yang terjadi pada diri manusia (Yamin, 2012).

Proses pembelajaran dituntut untuk membangun interaksi didalam kelas. Dan ini menjadi kewajiban dosen untuk merancang pelaksanaan pembelajaran dengan sebaik mungkin, agar kegiatan pembelajaran berhasil dan dapat meningkatkan aktivitas belajar mahasiswa didalam kelas. Hal-hal demikian dapat diwujudkan melalui penerapan metode yang tepat, yakni salah satunya, yaitu dengan menerapkan metode brainstorming. Melalui metode ini aktivitas oral akan meningkat, karena mahasiswa akan diberi kesempatan untuk mengemukakan pendapatnya dalam menyelesaikan prmasalahan. Kemudian aktivitas mentalnya juga akan meningkat, karena mahasiswa akan mengembangkan kemampuan berpikirnya dengan memikirkan solusi-solusi yang akan diungkapkanya, demikian dengan aktivitas-aktivitas lainya juga akan meningkat (Wina, 2008).

Sejalan dengan penelitian Barbara, Sara (2010) yang mengungkapkan bahwa "metode brainstorming adalah teknik diskusi kelompok dimana anggotanya menyatakan sebanyak mungkin ide-idenya atas topik tertentu tanpa hambatan dan pertimbangan aplikasi praktisnya. Spontanitas dan kreativitas merupakan bagian penting dalam curah pendapat penilaian terhadap ide-ide dilakukan pada sesi berikutnya". "Brainstorming adalah suatu teknik yang digunakan untuk menghasilkan suatu daftar panjang yang berisi berbagai respon berbeda tanpa membuat penilaian terhadap ide-ide individu".

Dengan demikian dapat disimpulkan bahwa metode brainstorming adalah suatu bentuk diskusi dimana peserta didorong untuk menyatakan gagasan, pendapat, informasi, pengetahuan, pengalaman serta ide-ide mengenai suatu masalah tanpa adanya penilaian dari peserta lain. Tujuan penggunaan metode brainstorming oleh M. Subana (2009) ialah "menguras habis segala sesuatu yang dipikirkan oleh siswa dalam menggapi masalah yang dilontarkan guru kepadanya". Agar tujuan dalam penerapan metode brainstorming dapat tercapai maka perlu adanya aturan yang diperhatikan. Hal ini dimaksudkan agar metode brainstorming dapat berjalan dengan efektif dan efisien sehingga tujuan yang diharapkan dapat terealisasi.

Pembelajaran menggunakan kasus adalah pembelajaran dengan berdasarkan masalah-masalah yang ditemukan di lapangan (Pusdiklat, 2004). Dengan pendekatan tersebut mahasiswa selain diberi pengetahuan tapi juga mahasiswa diberi pengetahuan untuk mengaplikasikan konsep yang diterimanya dari lingkungan nyata dan mempelajari keterkaitan keterkaitannya.

Penelitian yang relevan dengan penelitian ini yaitu penelitian yang dilaksanakan Ratih Khusnul Fatimah yaitu dengan judul: penerapan tekhnik pembelajaran branstorming untuk meningkatkan hasil belajar siswa di kelas VII C SMPN 2 Kecamatan Sawoo tahun pelajaran 2012/2013. Hasil penelitian tersebut menunjukkan bahwa penerapan teknik pembelajaran brainstorming pada siswa kelas VII C SMPN 2 Sawoo dapat meningkatkan hasil belajar siswa yaitu dari rata-rata 64,76 pada siklus I menjadi 85,6 pada siklus II. Ketuntasan hasil belajar mengalami kenaikan yaitu $32 \%$ pada siklus I menjadi $76 \%$ pada siklus II. Aktivitas siswa meningkat yaitu dari $23 \%$ dengan kategori kurang aktif pada siklus I menjadi $78 \%$ dengan kategori aktif pada siklus II. Kemampuan guru dalam mengelola kelas mengalami peningkatan yaitu dari nilai rata-rata 1,8 dengan kategori cukup pada siklus I menjadi 3,5 dengan kategori baik 
sekali pada siklus II. Respon siswa menunjukkan $83 \%$ respon yang setuju dengan kategori sangat tinggi (Ratih, 2013).

\section{SIMPULAN}

Hasil penelitian, dapat disimpulkan bahwa metode edukasi brainstorming sangat efektif digunakan dalam memahami kasus keperawatan di lahan praktik di bandingkan dengan metode konvensional, karena mahasiswa mampu mengemukakan pendapat masing-masing dalam suatu kasus di lahan praktik dan kelompok bisa mengambil suatu kesimpulan atas kasus yang di bahas bersama kelompok.

\section{SARAN}

Disarankan kepada pihak-pihak terkait, antara lain :

Bagi RS diharapkan bisa menerapkan metode edukasi brainstormingpada mahasiswa yang sedang praktik.

Bagi pelayanan keperwatan diharapkan dapat memberikan pembekalan dan simulasi pada mahasiswa profesi terkait metode edukasi brainstormingsebelum mahasiswa terjun kelapangan.

Bagi penelitian selanjutnya bisa mengembangkan analisis dan hasil lebih lanjut, khususnya memperdalam analisistentang variabel confounding.

\section{DAFTAR PUSTAKA}

Allman, B \& Freeman, S. (2010). Menjadi Guru Kreatif. Jogjakarta: Golden Book Balackova, H. (2004). Brainstorming: a Creative Problem Solving Method. Http://Www.Unido.Org//Fileadmin/Import/196953_Brainstorming.Pdf. Diakses pada 02 April 2017

Bastable, S. B. (2006). Perawat sebagai Pendidik: Prinsip-Prinsip Pengajaran dan pembelajaran. Jakarta: EGC

Fang, N. (2013). Increasing High School Students Interest in STEM Education Through Collaborative Brainstorming With Yo-Yos

Fatimah, R. K. (2013). Penerapan Teknik Pembelajaran Brainstorming untuk Meningkatkan Hasil Belajar Siswa di Kelas VII C SMPN 2 Kecamatan Sawoo Tahun Pelajaran 2012/2013, Skrpsi, Ponorogo: Universitas Muhammadyah Ponorogo

Karim. (2011). Penerapan Metode Penemuan Terbimbing dalam Pembelajaran atematika untuk Meningkatkan Pemahaman Konsep dan Kemampuan Berpikir Kritis Siswa Sekolah Dasar. Disajikan dalam Seminar Nasional Matematika Terapan. Pendidikan Guru Sekolah Dasar (PGSD) FKIP Universitas Almuslim

Kimberly, H. (2013). "Brainstorming Information", http://en.wikipedia. org/wiki/ Brainstorming, di unduh pada 2017/06/17 pukul 10.30 WIB

Notoatmodjo, S. (2007). Kesehatan Masyarakat Ilmu dan Seni. Jakarta: Rineka Cipta

Nuraisiyyah, I. (2008). Perbedaan Penguasaan Konsep Sistem Indera antara Metode Brainstorming dan Metode Tanya Jawab. Diakses 3 Maret 2017

Pusdiklat. (2004). Perencanaan Pelatihan, Pusdiklat Pegawai Depdikbud. Jakarta

Roestiyah. (2008). Strategi Belajar Mengajar. Jakarta: PT Rineka Cipta

Subana, M. (2009). Strategi Belajar Mengajar Bahasa Indonesia Berbagai Pendekatan, Metode Teknik dan Media Pengajaran. Bandung: CV Pustaka Setia

Suprijanto. (2009). Pendidikan Orang Dewasa. Jakarta: PT. Bumi Aksara 
Wina Sanjaya. (2008). Perencanaan dan Desain Sistem Pembelajaran. Jakarta: Kencana

Yamin. (2012). Taktik Mengembangkan Kemampuan Individual Peserta Didik. Jakarta

Zhao. (2010). The Study on Influencing Factor of Team Brainstorming Effectiveness.http://eresources.perpusnas..go.id:2057/docview/821296942/fulltext pdf/BE7AA3E382CD4E7APQ/1? accountid=25704. Diakses 01 April 2017 